\title{
KEBIJAKAN PENDIDIKAN DI ERA REVOLUSI 4.0: GAMIFIKASI PENDIDIKAN, MENGUBAH VIDEO GAME MENJADI PLATFORM
}

\author{
Deding Ishak \\ STAI YAPATA Al-Jawami, Bandung \\ Email: dedingishak@yahoo.com
}

\begin{abstract}
Abstrak
Beberapa penelitian terdahulu menemukan bahwa gamifikasi dapat menjadi alat yang sangat membatu dalam meningkatkan efektivitas murid dalam belajar. Namun sayangnya aplikasi penggunaan gamifikasi masih sangat terbatas. Akibatnya para pengajar masih ragu untuk mengadopsikan game sebagai alat mengajar karena faktor-faktor yang membatasinya, seperti kompleksitas game, rumitnya mengadaptasi kepada hasil yang diinginkan, lemahnya keterlibatan murid serta sulitnya untuk dimasukkan ke dalam kurikulum belajar. Penelitian ini menggunakan data-data yang berasal dari berbagai penelitian terdahulu, untuk kemudian dianalisis dan ditemukan kesimpulan. Hasil dari penelitian kemudian menunjukkan bahwa game sebagai platform pendidikan haruslah memiliki karakter berupa dapat beradaptasi ke berbagai tujuan pendidikan; memberikan akses pada pengajar untuk dapat mengontrol keterlibatan murid; menaik turunkan tingkat kesulitan untuk dapat menjaga tingkat kompleksitas yang diinginkan; dan tetap menjaga ketertarikan murid melalui penyeimbangan tingkat kesulitan dengan tingkat kemampuan murid.
\end{abstract}

Kata Kunci: Kebijakan, Pendidikan, Revolusi 4.0, Gamifikasi Pendidikan, Video Game, Platform.

\begin{abstract}
Several previous studies have found that gamification can be a very helpful tool in increasing student effectiveness in learning. But unfortunately, the application of gamification is still very limited. As a result, teachers are still hesitant to adopt games as a teaching tool because of the limiting factors, such as the complexity of the game, the complexity of adapting to the desired results, the lack of student involvement and the difficulty of incorporating it into the learning curriculum. This study uses data from various previous studies, to then be analyzed and found conclusions. The results of the research then show that the game as an educational platform must have a character in the form of being able to adapt to various educational goals; provide access for teachers to be able to control student engagement; increase and decrease the level of difficulty to be able to maintain the desired level of complexity; and maintain student interest by balancing the difficulty level with the student's ability level.
\end{abstract}

Keywords: Policy, Education, Revolution 4.0, Educational Gamification, Video Games, Platforms.

\section{A. PENDAHULUAN}

Dalam konteks umum, gamifikasi telah menjadi perhatian para ahli dalam beberapa tahun terakhir. Gartner memprediksikan bahwa dalam waktu dekat sebanyak 50\% organisasi akan melakukan gamifikasi sebagai proses inovasi milik mereka (Hamari, 2017). Sementara itu, dalam bidang pendidikan sendiri gamifikasi belum sepenuhnya berhasil diimplementasikan, walau telah banyak bukti yang mendukung keberhasilan dari gamifikasi 
tersebut. Beberapa penelitian terdahulu menunjukkan bahwa sering kali para pengajar dalam dunia pendidikan menghindari penggunaan game di kelasnya karena sulitnya proses kurva belajar, kurangnya keramahan bagi pengguna baru, tidak fleksibelnya hubungan antara game dengan pelajaran, dan permasalahan biaya yang diperlukan (Negrusa et al., 2015). Selain itu, para pengajar juga khawatir akan dampak negatif yang dapat ditimbulkan oleh game di kelas, seperti persaingan yang tidak sehat di antara para murid, tidak terkontrolnya perilaku murid serta kecanduan game. Berdasarkan pendapat dari Joel Klein, sebagian besar game pendidikan tidak didesain untuk menyenangkan para murid, sehingga kemudian hal ini berakibat kepada kurangnya ketertarikan serta kemauan murid untuk dapat menginvestasikan waktu dan usahanya dalam bermain game pendidikan (Yates, 2013).

Sementara itu, lebih dari $90 \%$ remaja menghabiskan waktu kosong miliknya untuk dapat bermain video game. Bahkan beberapa remaja dapat menghabiskan waktu lebih dari 25 jam dalam seminggu untuk bermain game saja (Simons et al., 2012). Kemudian game online memiliki sifat yang jauh lebih popular pada masa ini. Game online seperti Free Fire memiliki jumlah pemain hingga 80 juta orang per hari dan dapat menghasilkan hingga lebih dari 100 juta dolar setiap tahunnya (Suryono, 2016). Banyak sekali fitur-fitur yang dimiliki oleh game yang kemudian dapat membuat pemainnya merasa kecanduan. Berdasarkan perusahaan Amplify Learning, game yang baik adalah game yang memiliki kapasitas untuk dapat membuat seseorang terlibat dengan tugas-tugas intens dan membutuhkan kognitif tinggi dalam waktu yang lama (Pass \& Sweller, 2012). Ketika beberapa peneliti berpendapat bahwa rasa kecanduan pada dasarnya merupakan hal yang buruk dan perlu untuk dihindari, namun peneliti lainnya berpendapat bahwa rasa kecanduan ini dapat disalurkan melalui jalan yang positif untuk dapat membangun perilaku yang bersifat konstruktif seperti belajar sehingga dapat memiliki manfaat yang baik (Goleman, 2000).

Beberapa peneliti menganggap bahwa game pendidikan dapat didesain untuk menyelesaikan berbagai permasalahan yang membatasinya untuk tujuan pendidikan. Para ahli ini kemudian mencari pengembangan dan mengevaluasi teori yang digunakan untuk mendesain suatu game menjadi game pendidikan (Novidayanti, 2018). Oleh karena itu, peneliti kemudian tertarik untuk melihat bagaimana langkah yang digunakan untuk dapat melakukan gamifikasi pendidikan agar dapat mengubah game menjadi suatu platform yang bersifat mendidik namun tetap menarik minat murid dalam belajar tanpa kehilangan fungsi dan tujuan utamanya.

\section{B. KAJIAN LITERATUR}

\section{Pendidikan}

Socrates dan Plato telah mencari definisi mengenai pendidikan sejak dahulu kala (Digdowiseiso, 2020). Terdapat banyak sekali definisi yang berbeda-beda mengenai arti dari pendidikan. Walaupun terdapat banyak sekali definisi yang ada, Matheson dan Wells berpendapat bahwa tidak akan nada definisi yang memuaskan mengenai arti pendidikan yang lengkap (Parma et al., 2018). Menurut Gregory, pendidikan merupakan usaha seseorang dalam mencoba memahami arti sosial, fisik dan budaya dengan menggunakan otak dan pikiran miliknya (Rahmiana, 2019). Pendapat lain dari Peter mengenai pendidikan adalah suatu usaha implikasi ketika manusia mencoba untuk dapat mentransmisikan sesuatu yang dapat dianggap berguna atau tidak sia-sia (Lobodally, 2014). 
Sulitnya mendefinisikan pendidikan karena makna tersebut dapat berubah tergantung setiap konteks yang mengikutinya, sehingga makna pendidikan kemudian selalu berubah-ubah dan tidak pasti. Sebagian ahli berpendapat bahwa sekolah dapat diartikan sebagai suatu pendidikan, sementara beberapa ahli lain berpendapat bahwa kegiatan belajar mengajar dapat terjadi di mana saja dan kapan saja, sehingga hal ini tidak memerlukan istilah pendidikan (Triana, 2018).

Perbedaan-perbedaan ini kemudian memberikan pertanyaan baru, apakah produk hasil belajar merupakan bentuk asli dari pendidikan, ataukah proses yang terjadi selama pendidikan adalah bagian terpenting dari pendidikan itu sendiri. Kemunculan dari pertanyaan ini kemudian menunjukkan bahwa konsensus mengenai definisi pendidikan masih belum ada di antara para ahli sekalipun (Efferi, 2014). Selain dari sulitnya mendefinisikan arti pendidikan, kriteriakriteria dalam pendidikan juga masih mengalami perdebatan (Yuhana \& Aminy, 2019).

Wittgenstein kemudian memberikan awal yang baik untuk memahami pengertian dari pendidikan. Wittgenstein berpendapat bahwa setiap konteks dapat memberikan arti yang berbeda kepada suatu kata yang sama (Wahyudi \& Suyitno, 2018). Sering kali suatu istilah memiliki banyak sekali arti yang berbeda, namun setidaknya istilah tersebut tetaplah memiliki fungsi yang sama di setiap konteks yang berbeda (Suharyanto, 2016).

Pendekatan yang berasal dari Wittgenstein dapat memberikan pengertian dari pendidikan, di mana hal ini tergantung dari konteks yang akan digunakannya. Oleh karena itu, maka hal ini memungkinkan kita untuk mendapatkan definisi dari suatu istilah yang dapat memiliki banyak arti (Amirudin, 2017).

\section{Game}

Game (atau sering juga disebut sebagai video game) merupakan perangkat permainan yang melibatkan interaksi yang terjadi di antara pemain dengan seperangkat input dalam permainan tersebut sehingga kemudian dapat menghasilkan umpan balik yang berbentuk visual. Umpan balik ini sering kali dimunculkan di dalam bentuk layar seperti TV, monitor dan sebagainya. Melalui perkembangan yang ada, sering kali game hadir dengan umpan balik berbentuk tambahan suara yang dimunculkan melalui speaker ataupun headphone (Lange et al., 2012).

Definisi mengenai game terkadang dapat bersifat cukup kompleks, di mana beberapa game memiliki kejelasan sebagai sebuah game, beberapa genre dan inovasi-inovasi baru yang terus dilakukan akan menciptakan berbagai pertanyaan baru, yaitu faktor apakah yang membedakan suatu game dengan media lainnya yang memiliki kemiripan yang sama dengan tujuan untuk menghibur (Linderoth, 2012).

Hal ini dikarenakan terdapat beberapa contoh seperti film interaktif yang muncul pada tahun 1980, di mana terdapat adanya suatu game berbentuk video, namun hanya memiliki interaksi yang sangat terbatas, sehingga kemudian hal ini memerlukan suatu pembeda yang pasti agar kemudian dapat membedakan media mana yang merupakan sebuah game, dan media mana yang bukan (Kaplan \& Haenlein, 2010).

Banyak sekali game yang memberikan fitur-fitur seperti memenangkan sesuatu atau berhasil menyelesaikan tujuan akhir dari game tersebut. Hal ini dapat dilakukan melalui pemberian bos terakhir untuk di kalahkan atau melalui mekanisme dalam game seperti menyelesaikan semua tugas atau mengumpulkan semua poin (Aditya, 2018). Kemudian 
kemunculan beberapa genre baru dalam game yang memberikan kebebasan dalam bereksplorasi tanpa memiliki tujuan khusus atau game yang berfokus kepada rasa sosial dan emosi memberikan ide baru bahwa game tidak selalu memerlukan suatu kondisi untuk dapat dimenangkan serta kemudian muncul pula pertanyaan, apakah hal-hal seperti ini dapat dianggap sebagai sebuah permainan (Suhendini, 2015). Dalam komunitas sendiri, hal-hal seperti ini masih dapat dianggap sebagai suatu game karena terdapat adanya interaksi yang terjadi oleh para pemain melalui cara-cara tertentu.

\section{METODE}

Penelitian ini dilakukan dengan menggunakan data-data yang diperoleh melalui jurnal, buku atau artikel online yang masih memiliki keterhubungan dan tema yang sama mengenai penelitian ini seperti gamifikasi pendidikan, pembuatan platform serta pendidikan yang sifatnya interaktif. Hasil dari data-data yang telah berhasil dikumpulkan ini kemudian dianalisis sesuai dengan tujuan dari fokus penelitian sebagai pedoman, sehingga kemudian dapat menghasilkan kesimpulan yang diharapkan.

\section{HASIL DAN PEMBAHASAN}

\section{Gamifikasi dan Hambatannya}

Penelitian mengenai fenomena gamifikasi telah mendapatkan cukup banyak perhatian oleh para peneliti. Hal ini dapat di lihat bahwa pada tahun 2011 hanya terdapat 6 artikel yang membahas mengenai gamifikasi. Kemudian pada tahun 2014 jumlah artikel ini bertambah menjadi 106 dan terus bertambah hingga tahun ini. Walaupun begitu, sebagian besar penelitian tersebut berfokus kepada penggunaan gamifikasi terhadap pengaturan bisnis. Banyak sekali perusahaan yang mencoba mengembangkan dan mengimplementasikan game ke dalam perusahaan mereka agar dapat meningkatkan proses bekerja, seperti dalam proses rekrutmen, pelatihan hingga pemasaran.

Gamifikasi dapat didefinisikan sebagai upaya yang dilakukan untuk mengaplikasikan mekanik game dalam hal yang bukan merupakan game (Leaning, 2015). Hal ini dilakukan dengan tujuan agar para pengguna berkompetisi satu sama lain dengan tujuan memberikan hasil yang lebih baik. Hal ini dapat diimplementasikan oleh perusahaan kepada karyawannya melalui sistem poin atas keberhasilan dan sebagainya.

Banyak sekali penelitian menemukan bahwa aplikasi gamifikasi dalam konteks organisasi dan perusahaan memberikan hasil-hasil yang memuaskan. Namun sayangnya cukup sedikit penelitian yang membahas dan menemukan hasil dari gamifikasi dalam proses pendidikan. Terdapat adanya upaya yang telah berhasil dilaksanakan untuk melakukan gamifikasi terhadap pendidikan. Contoh dalam hal ini adalah penggunaan Assassin's Creed Discovery Tour yang menjelaskan mengenai sejarah Mesir pada zaman dahulu di beberapa kelas sejarah.

Walaupun begitu, masih banyak pengajar yang cukup ragu untuk memasukkan game sebagai alat bantu mereka dalam belajar walaupun telah terbukti kegunaannya. Salah satu alasan yang membuat gamifikasi dapat berhasil dalam dunia industri dan tidak dalam bidang pendidikan adalah tingkat kecanggihan yang diinginkan oleh para murid dalam suatu game. Squire berpendapat bahwa sering kali murid berharap mengenai beberapa fitur dasar yang berada di dalam game untuk dapat dimasukkan ke dalam game pendidikan yang sering kali 
tidak muncul. Oleh karenanya perlu adanya suatu prinsip-prinsip dasar yang dimiliki suatu game pendidikan dan berasal dari game biasa seperti cerita, tujuan, tema fantasi dan sebagainya.

Walau desain-desain tersebut cukup penting untuk dapat menarik minat para murid, terdapat adanya beberapa faktor yang mempengaruhi para pengajar untuk menggunakan game pendidikan di kelasnya. Faktor-faktor tersebut kemudian dapat di bagi menjadi lima kategori, yaitu sumber daya, kesiapan, fleksibilitas game, kegunaan dan efek samping. Adapun penjabaran dari faktor tersebut adalah sebagai berikut:

a. Sumber daya

1). Waktu. Waktu yang dibutuhkan untuk dapat menemukan, menyiapkan serta mengadaptasi game cukup panjang

2). Biaya. Biaya yang dibutuhkan agar dapat menggunakan game sebagai alat bantu dalam pendidikan cukup tinggi

b. Kesiapan

1). Level kesiapan murid. Kemampuan murid yang bervariasi dalam menghadapi kompleksitas yang dapat diberikan oleh game, serta kemampuan game dalam mengikuti kemampuan murid

2). Level kesiapan pengajar. Kemampuan pengajar dalam menjalankan dan mengoperasikan game, serta kesesuaian game dengan bahan ajar dan kemampuan pengajar dalam mengajar

c. Fleksibilitas Game

1). Kesesuaian game dengan konten materi. Cukup sulit untuk menemukan game yang tepat dengan kurikulum yang akan diajarkan, di mana game tidak mudah untuk diadaptasi menjadi alat ajar.

2). Kesesuaian dengan struktur konten. Game sering kali memiliki waktu yang terlalu lama dan sulit untuk dapat sesuai dengan waktu yang tersedia serta tidak dapat disesuaikan sesuka hati dengan waktu yang dimiliki oleh pengajar.

3). Kesesuaian dengan struktur grup. Jumlah pemain yang dibutuhkan oleh suatu game sering kali tidak dapat dimodifikasi, sehingga sulit untuk menjalankan game apabila terdapat hal yang tak terduga.

d. Kegunaan

1). Tingkatan Pembelajaran. Game sering kali lebih berfokus kepada simulasi dan pengalaman dibandingkan tujuannya dalam mendidik

2). Tingkat ketertarikan. Game yang hanya berfokus kepada tujuan pendidikan sering kali bersifat tidak menarik bagi para murid sehingga menjadi tidak menarik dan menggagalkan tujuan dari game itu sendiri.

3). Kualitas game. Game dapat menjadi rusak atau bahkan tidak lengkap, di mana hal ini kemudian akan membuang waktu pengajar dan murid serta mengurangi proses belajar.

e. Efek Samping

1). Kecanduan. Bermain game dapat memberikan murid perilaku kecanduan yang mengganggu proses belajar.

2). Persaingan tidak sehat. Para murid dapat menjadi terobsesi dengan kemenangan dan mengganggu proses belajar 


\section{Desain Dasar dalam Game Pendidikan}

Melalui hasil analisis, ditemukan adanya peningkatan kesuksesan dalam mengimplementasikan game di dalam konteks bisnis dan entertaimen, namun tidak dengan bidang pendidikan. Keuntungan yang diperoleh oleh game sendiri dapat mencapai beberapa kali lipat dibandingkan bidang hiburan lainnya seperti musik, buku dan film. Beberapa perusahaan besar seperti Toyota dan SAP telah menggunakan game sebagai cara untuk dapat meningkatkan efektivitas operasional dan efisiensi (Rigby et al., 2018). Namun upaya untuk mengadopsi game ke dalam bidang pendidikan masih muncul seperti yang telah dijelaskan di atas. Kemunculan dari faktor-faktor yang menghalangi game sebagai media pendidikan mungkin disebabkan oleh karakteristik dari game tersebut. Hal ini dapat terjadi karena pembuat game tersebut tidak menggunakan prinsip yang benar ketika membuatnya.

Agar dapat menemukan desain yang tepat, maka prinsip dasar pembuatan game dapat ditemukan ketika menentukan tujuan dari pembuatan game tersebut. Setidaknya peneliti menemukan bahwa game pendidikan haruslah dapat menjadi platform yang baik, dapat mengontrol interaksi murid serta menjaga kepuasan murid.

a. Game Sebagai Sebuah Platform

Desain game pendidikan yang diinginkan perlu memiliki kemampuan untuk dapat menyelesaikan permasalahan-permasalahan yang telah disebutkan di atas, namun juga masih mengikuti tujuannya sebagai alat untuk belajar. Permasalahan pertama yang muncul dalam menggunakan game pendidikan sebagai media pembelajaran adalah menemukan game yang tepat dan dibutuhkan oleh pengajar. Walaupun pengajar mendapatkan keuntungan melalui game pendidikan karena dapat melibatkan murid lebih jauh serta mengikutsertakan mereka dalam alat pengajaran, hampir mustahil untuk menemukan suatu game yang cukup komprehensif untuk dijadikan alat belajar dibandingkan alat-alat belajar lainnya. Penelitian berfokus kepada sedikitnya game pendidikan yang sering kali tidak memuaskan pengajar akan hasil yang didapat serta sifatnya yang terlalu kaku. Hal ini dikarenakan sering kali game pendidikan dibuat oleh pengajar atau pihak sekolah dengan tujuan untuk mendapatkan pengetahuan yang sifatnya cukup spesifik dan diberikan di institusi tersebut. Selain itu, walaupun terkadang ada kemiripan di antara satu pelajar dengan pelajaran lainnya, perbedaan ini akan muncul ketika berasal dari suatu institusi yang berbeda dengan level pelajaran yang berbeda juga. Ketika game pendidikan kemudian berubah sifatnya menjadi terkomputerisasi, maka hal ini kemudian akan semakin menyulitkan para pengajar yang ingin menggunakan game ini untuk mengganti konten, tingkat kompleksitas, serta alur mengajarnya. Oleh karenanya peneliti mengajukan hal berupa:

1). Prinsip desain game pendidikan nomor satu, game pendidikan harus sengaja dibuat di atas platform game yang bisa beradaptasi dengan berbagai tujuan dan bidang pendidikan yang berbeda

2). Prinsip desain game pendidikan nomor dua, game pendidikan harus sengaja dibuat di atas platform game yang bisa diatur skalanya agar dapat mencapai tingkat kerumitan yang diinginkan atau dibutuhkan.

Platform game yang dapat beradaptasi kepada berbagai tujuan pendidikan dan skala kompleksitas akan membuat pengajar dapat menggunakan platform tersebut berkalikali dalam konteks yang berbeda. Hal ini kemudian akan menurunkan biaya yang 
dibutuhkan untuk membeli game yang berbeda dengan tiap tujuan dan skala game yang berbeda. Selain itu, karena penggunaan berulang-ulang ini, maka kesiapan tenaga pengajar dalam menggunakan game pendidikan tersebut akan terus bertambah setiap saatnya. Namun demikian platform tersebut perlu untuk dapat dikonfigurasi sehingga para pengajar dapat membuat game pendidikan baru atau mengadaptasi game pendidikan sebelumnya sehingga waktu yang akan dibutuhkan akan semakin sedikit. Oleh karena itu kemudian peneliti mengajukan prinsip berikutnya berupa:

3). Prinsip desain game pendidikan nomor tiga, platform game pendidikan harus dapat dengan mudah dikonfigurasi agar memungkinkan bagi pengajar untuk dapat mendesain arus kerja game tersebut dengan cepat.

Suatu platform game yang dapat beradaptasi terhadap berbagai tujuan dan skala pendidikan ke dalam berbagai tingkatan kompleksitas yang berbeda dapat mempertahankan tujuan pembelajaran yang diinginkan melalui pembatasan tertentu sesuai dengan struktur grup dan waktu yang dimiliki. Selain itu, tingkat kerumitan game pendidikan yang dapat diatur oleh tenaga pengajar akan membantu pengajar dalam mendesain game pendidikan sesuai dengan kompleksitas yang dibutuhkan dan sesuai dengan kapasitas murid. Platform tersebut juga perlu untuk membuat pengajar dapat menentukan seberapa dalam topik yang ingin dicapai dalam proses belajar tersebut.

b. Platform Sebagai Alat Pengontrol Keterlibatan Murid

Walaupun platform game pendidikan yang telah diimplementasikan dengan prinsip desain di atas dapat menyelesaikan beberapa permasalahan yang menyebabkan sulitnya game diadopsi ke dalam media pendidikan, namun hal ini justru dapat memperburuk masalah lainnya. Salah satu faktor yang menyebabkan game sulit untuk diadopsi ke dalam media pendidikan adalah suatu game dapat bersifat terlalu menyenangkan dan sering tidak bermanfaat, atau justru terlalu membosankan dan tidak menarik. Ketika permainan yang ada terlalu menyenangkan, maka perilaku murid akan semakin sulit di kendalikan dan pelajaran yang berhasil diterima akan semakin berkurang. Hal ini dikarenakan murid sering kali menunjukkan perilaku kecanduan dan memiliki tingkat kompetensi yang tidak sehat. Namun di sisi lain, jika game tersebut tidak menyenangkan, maka murid akan mudah bosan dan tidak lagi tertarik. Hal ini semakin menjadi kenyataan jika pengajar menggunakan platform yang sama berkali-kali. Murid yang merasa tidak tertarik akan mengurangi interaksi mereka, sehingga mengurangi pelajar yang akan didapatkan.

Kemampuan untuk dapat menyeimbangkan keseruan yang dimiliki dengan pendidikan yang harus diperoleh memerlukan desain platform game pendidikan yang memungkinkan pengajar untuk dapat mengendalikan tingkat kesenangan murid. Artinya para pengajar harus dapat membuat murid mencapai tingkat kesenangan yang cukup dalam beraktivitas tanpa mencapai tingkat imersi yang terlalu tinggi di dalam game pendidikan. Telah terdapat banyak sekali penelitian mengenai cara mempertahankan tingginya tingkat keterlibatan, di mana salah satunya merupakan literatur mengenai kecanduan game. Kecanduan game merupakan perasaan yang dimiliki seseorang ketika sulit untuk mengendalikan dirinya untuk tidak bermain game. Para pecandu game biasanya memiliki keinginan untuk melanjutkan aktivitas bermain yang dimilikinya agar dapat menyalurkan rasa euforia yang di dapat ketika bermain 
game serta mencoba untuk menghindari emosi yang tidak diinginkan sebagai akibat dari penghentian aktivitas sementara ketika seseorang berhenti bermain game. Hasil penelitian terdahulu yang meneliti mengenai kecanduan game menunjukkan bahwa beberapa game memiliki fitur-fitur yang dapat mengakibatkan rasa adiktif, sehingga kemudian hal ini akan meningkatkan jumlah waktu yang digunakan dalam bermain game.

Beberapa fitur game menyebabkan adanya keterlibatan tingkat tinggi dari pemain sehingga kemudian dapat menyebabkan terjadinya kecanduan dan mengakibatkan umpan balik yang menyenangkan seperti menstimulasi perilaku repetitif, kompetisi atau kerja sama antar banyak pemain, hingga sistem hadiah dan reputasi. Terlepas dari adanya kemungkinan buruk yang berasal dari fitur-fitur game ini serta kontribusi yang diberikan kepada kecanduan game, dapat dikatakan bahwa, jika dapat dikendalikan, maka hal ini dapat memberikan peran yang bersifat konstruktif bagi keterlibatan murid tanpa menciptakan adanya kecanduan. Tingkat keterlibatan dari murid dengan game tersebut berada di antara tidak ada keterlibatan sama sekali hingga keterlibatan penuh. Oleh karena itu peneliti menganggap bahwa unsur keterlibatan ini sebaiknya tidak menjadi bagian dari game pendidikan, namun justru diatur secara langsung oleh pengajar dalam menentukan keterlibatan murid-muridnya. Oleh karenanya peneliti memberikan desain lanjutan berupa:

1). Prinsip desain game pendidikan nomor empat, platform pendidikan haruslah memungkinkan pengajar untuk dapat mengaktifkan dan menonaktifkan fitur-fitur yang dapat membuat murid kecanduan

2). Prinsip desain game pendidikan nomor lima, platform pendidikan haruslah memungkinkan pengajar untuk menciptakan game pada berbagai tingkatan interaksi yang terjadi di antara murid

3). Prinsip desain game pendidikan nomor enam, platform pendidikan harus memungkinkan pengajar untuk dapat menentukan tingkatan umpan balik yang akan menyenangkan murid

c. Platform Game Pendidikan Sebagai Alat Pengontrol Gairah Murid

Terdapat adanya flow teori yang menjelaskan bagaimana keterlibatan tinggi yang menyenangkan dapat diperoleh dalam suatu aktivitas. Dalam teori ini, dijelaskan bagaimana tingkat kesulitan tugas serta tingkat keahlian yang dimiliki oleh seseorang akan berperan penting dalam hal yang akan dirasakan oleh orang tersebut. Ketika kesulitan yang ada cukup rendah, maka orang dengan tingkat kemampuan tinggi akan merasakan kebosanan, sementara orang yang memiliki kemampuan rendah tidak akan terlalu peduli. Untuk menarik minat seseorang, maka tugas yang dikerjakan harus cukup tinggi. Ketika kesulitan yang ada melebihi kemampuan yang dimiliki orang tersebut, maka merela akan merasakan kecemasan. Namun ketika orang tersebut berhasil mengendalikan situasi sulit tersebut, maka orang tersebut kemudian akan menikmati tugas yang diterima. Rasa senang sebagai akibat dari berhasilnya melaksanakan tugas yang ada akan menumbuhkan motivasi untuk melakukan tugas tersebut kembali.

Pada umumnya game dilihat sebagai suatu hal yang dapat menimbulkan terjadinya rasa ketertarikan untuk dilakukan terus menerus. Tentunya memang game memiliki 
beberapa syarat agar dapat memenuhi kondisi ketertarikan ini. Karena sifatnya yang menarik ini, maka game dapat meningkatkan motivasi serta dapat menjadi alat yang baik untuk belajar. Para ahli berpendapat bahwa jika berhasil didesain untuk dapat terus meningkatkan ketertarikan, maka game pendidikan dapat menjadi cara yang tepat bagi murid untuk mencapai tujuan mereka dalam belajar. Kiili berpendapat bahwa game pendidikan harus bertujuan untuk dapat menjaga ketertarikan muridnya secara konstan melalui keseimbangan keahlian dengan tantangan yang dihadapinya untuk menghindari rasa bosan dan cemas.

Namun sayangnya menjaga ketertarikan murid secara konstan cukup sulit bagi game yang bertujuan untuk mendidik. Menekankan kepada tujuannya dalam pendidikan, peneliti berpendapat bahwa game pendidikan harus dapat tetap menjaga gairah dari murid secara konstan, dan bukan masalah ketertarikan. Melalui peningkatan kesulitan yang dilakukan secara bertahap, maka tingkat keahlian para murid juga dapat bertambah secara perlahan mengikuti tingkat kesulitan yang ada, sehingga hal ini kemudian akan tetap menjaga tingkat keterlibatan yang dimiliki oleh para murid dan secara bersamaan tetap membuat mereka dapat belajar. Oleh karena itu, peneliti memberikan desain terakhir berupa desain game pendidikan nomor tujuh, platform pendidikan harus tetap membuat murid merasa bergairah secara konstan melalui penambahan tingkat kesulitan game di atas kemampuan murid sebanyak satu tingkatan.

\section{E. KESIMPULAN}

Pendidikan secara bertahap mulai berubah dari fokus kepada pendekatan perkuliahan menjadi pendekatan yang lebih bersifat eksperimental. Game pendidikan dapat menguntungkan bagi murid karena hal ini dapat menyimulasikan dunia nyata serta memberikan keterlibatan langsung mengenai topik yang dipelajari. Namun sayangnya masih banyak pengajar yang cukup ragu untuk menggunakan game sebagai alat bantu dalam belajar. Hal ini dikarenakan beberapa faktor yang mempersulit penyeimbangan terhadap biaya, keterlibatan dan pendidikan yang akan diterima oleh murid. Oleh karena itu peneliti kemudian mencoba untuk membuat desain platform bagi game pendidikan yang dapat menghindari berbagai faktor-faktor yang dapat menghambat penggunaan game dalam dunia pendidikan.

\section{REFERENSI}

Aditya, G. (2018). Perancangan Casual Game Android "Carbon Defender" dengan Konten Pembakaran Senyawa Hidrokarbon (Doctoral Dissertation, Institut Teknologi Sepuluh Nopember).

Amirudin, N. (2017). Pendidikan Humanisme dalam Perspektif Islam (Konsep dan Implementasinya dalam Pengelolaan Kelas). Jurnal TAMADDUN.

Digdowiseiso, K. (2020). The Development of Higher Education in Indonesia. International Journal of Scientific \& Technology Research, 9(2).

Efferi, A. (2014). Dinamika Persaingan Antar Lembaga Pendidikan. Quality, 2(1), 96-116.

Goleman, D. (2000). Kecerdasan emosional. Jakarta: Gramedia Pustaka Utama.

Hamari, J. (2017). Do badges increase user activity? A field experiment on the effects of gamification. Computers in human behavior, 71, 469-478. 
Kaplan, A. M., \& Haenlein, M. (2010). Users of the world, unite! The challenges and opportunities of Social-Media. Business horizons, 53(1), 59-68.

Lange, B., Koenig, S., Chang, C. Y., McConnell, E., Suma, E., Bolas, M., \& Rizzo, A. (2012). Designing informed game-based rehabilitation tasks leveraging advances in virtual reality. Disability and rehabilitation, 34(22), 1863-1870.

Leaning, M. (2015). A study of the use of games and gamification to enhance student engagement, experience and achievement on a theory-based course of an undergraduate media degree. Journal of Media Practice, 16(2), 155-170.

Linderoth, J. (2012). Why gamers don't learn more: An ecological approach to games as learning environments. Journal of Gaming \& Virtual Worlds, 4(1), 45-62.

Lobodally, A. (2014). Transformasi Simbolik Homoseksual di Televisi (Sebuah Studi Analisis Semiotika Barthes dan Semiotika Sosial MAK Halliday dalam Program CS: File Kompas TV). SEMIOTIKA: Jurnal Komunikasi, 8(1).

Negruşa, A. L., Toader, V., Sofică, A., Tutunea, M. F., \& Rus, R. V. (2015). Exploring gamification techniques and applications for sustainable tourism. Sustainability, 7(8), 11160-11189.

Novidayanti, R. (2018). Pengembangan Perangkat Pembelajaran Matematika Berbasis Whole Brain Teaching Pada Siswa SMP Swasta Al-Hikmah Medan TP 2017/2018. Medan: Universitas Muhammadiyah Sumatera Utara.

Paas, F., \& Sweller, J. (2012). An evolutionary upgrade of cognitive load theory: Using the human motor system and collaboration to support the learning of complex cognitive tasks. Educational Psychology Review, 24(1), 27-45.

Parma, I. P. G., Ariana, I. N. J., Putri, I. A. T. E., Putra, A. M., Sulistyawati, A. S., Suarka, F. M., ... \& Saharjo, S. J. (2018). Jurnal Perhotelan dan Pariwisata Triatma Jaya JULIDESEMBER 2017. Sekolah Tinggi Pariwisata Triatma Jaya, 7(2), 1-139.

Rahmiana, R. (2019). Komunikasi Intrapersonal dalam Komunikasi Islam. Jurnal Peurawi: Media Kajian Komunikasi Islam, 2(1), 77-90.

Rigby, D. K., Sutherland, J., \& Noble, A. (2018). Agile at scale. Harvard Business Review, 96(3), 88-96.

Simons, M., Bernaards, C., \& Slinger, J. (2012). Active gaming in Dutch adolescents: a descriptive study. International Journal of Behavioral Nutrition and Physical Activity, 9(1), 1-9.

Suharyanto, A. (2016). Surat kabar sebagai salah satu media penyampaian informasi politik pada partisipasi politik masyarakat. Jurnal Administrasi Publik: Public Administration Journal, 6(2), 123-136.

Suhendini, A. (2015). Perancangan Card Game Adaptasi Karya Klasik Cina" shui Hu Zhuan" Sebagai Media Pendidikan Anti Korupsi Bagi Generasi Muda. eProceedings of Art \& Design, 2(3).

Suryono, R. R. (2016). Perilaku Pemain Game Online terhadap Pembelian Virtual Item (Doctoral dissertation, Institut Teknologi Sepuluh Nopember).

Triana, R. (2018). Internalisisi Jihad Dalam Pendidikan Karater. Edukasi Islami: Jurnal Pendidikan Islam, 7(01), 101-129.

Wahyudi, W., \& Suyitno, H. (2018). Dampak Perubahan Paradigma Baru Matematika Terhadap Kurikulum dan Pembelajaran Matematika di Indonesia. INOPENDAS: Jurnal Ilmiah Kependidikan, 1(1).

Yates, L. (2013). Revisiting curriculum, the numbers game and the inequality problem. Journal of Curriculum Studies, 45(1), 39-51.

Yuhana, A. N., \& Aminy, F. A. (2019). Optimalisasi peran guru pendidikan agama Islam sebagai konselor dalam mengatasi masalah belajar siswa. Jurnal Penelitian Pendidikan Islam, 7(1), 79-96. 